Original Article

\title{
GLYCATION INHIBITORS AND PROBIOTICS CAN AMELIORATE THE CHANGES CAUSED BY HIGH FRUCTOSE FEED
}

\author{
RAHUL S. PATIL, ASHWINI D. JAGDALE, MEGHA L. NALAWADE, LAXMAN N. BAVKAR, AKALPITA U. \\ ARVINDEKAR*
}

Department of Biochemistry, Shivaji University, Kolhapur 416004 (M. S.), India

Email: drauarvindekar@yahoo.co.in

Received: 22 Apr 2018 Revised and Accepted: 01 Jun 2018

\section{ABSTRACT}

Objective: To evaluate the use of protein glycation inhibitors and probiotics to ameliorate secondary complications in diabetes and to improve gut microbiota respectively in high fructose fed Wistar rat.

Methods: The study was conducted on male Wistar rats for $7 \mathrm{~d}$. Blood glucose levels in oral glucose tolerance test (OGTT) were measured using glucometer, serum parameters were analyzed using commercial kits, antioxidant status was evaluated by measuring superoxide dismutase (SOD) and catalase (CAT) levels, total reactive oxygen species were estimated using a fluorescent 2', 7'-dichlorofluorescin diacetate (DCF-DA) dye, and tissue fluorescence of liver, kidney and intestine were measured using a spectrofluorimeter.

Results: OGTT pattern shows significant increase in blood glucose of fructose fed rats i.e. $154 \mathrm{mg} / \mathrm{dl}$ while, in aminoguanidine (AMG) treated and gut microbiota modulated animals it is 137 and $119 \mathrm{mg} / \mathrm{dl}$ resp. after $30 \mathrm{~min}$ on glucose administration. Marked reduction was found in SOD 6.37 and $11.25 \mathrm{U} / \mathrm{mg}$ of protein and catalase 186 and $65.5 \mathrm{U} / \mathrm{mg}$ of protein in liver and kidney of fructose fed animals when compared to fructose+AMG and fructose+EUGI. There is 5-6 fold significant increase in general and specific tissue fluorescence of liver and kidney, and 2.2 fold increase in liver reactive oxygen species was observed in fructose fed group as compare to control animals. Significantly higher glycation was found in intestine of fructose fed animals (general fluorescence 2.1 and specific fluorescence $3.1 \mathrm{AU} / \mathrm{mg}$ ), more than that of diabetic control rats (general fluorescence 0.9 and specific fluorescence $1.6 \mathrm{AU} / \mathrm{mg}$ ), represented an evidence for adverse impact of excess fructose on healthy gut.

Conclusion: The use of protein glycation inhibitor and use of pre and probiotics significantly improved the serum parameters and would prevent progression to secondary complications.

Keywords: Fructose, Glycation, Glycation inhibitors, Probiotics, Diabetes mellitus

(C) 2018 The Authors. Published by Innovare Academic Sciences Pvt Ltd. This is an open access article under the CC BY license (http://creativecommons.org/licenses/by/4.0/) DOI: http://dx.doi.org/10.22159/ijpps.2018v10i7.26870

\section{INTRODUCTION}

Diabetes mellitus is known to initiate several changes in various tissues of the body. Chronic hyperglycemia can eventually lead to secondary complications of diabetes such as nephropathy, neuropathy, retinopathy and cardio vascular diseases (CVD). The underlying causes involve glycation of proteins, oxidative stress, and involvement of immunological response and eventual destruction of tissues through multifactorial events. Protein glycation is known to cause changes in the protein structure such as alpha beta transitions, changes in the charge on the protein and electrophoretic mobility of the protein [1]. This is initiated through Amadori rearrangement, and formation of Advanced Glycation Products (AGEs) through Maillard reactions. The AGEs influence the functionality of the proteins and changes their clearance pattern. It is likely that continued impact of food with high glycemic index and sugars can initiate such changes.

Throughout the life ecological aspect shapes the microbial diversity of an individual and the mutualistic symbiosis in between them, majorly contributes a steady microbiota [2-4]. While, such changes in the gut may influence the gut microbial flora. Earlier reports have demonstrated a change in gut microflora in diabetics [5-7].

The use of probiotics has been suggested to influence this distribution and promote healthy outcomes. The probiotic bacteria like Lactobacillus acidophilus, Lactobacillus rhamnosus, Bifidobacterium longum, Bifidobacterium bifidum, Streptococcus thermophiles and Yeast Saccharomyces boulardii are found to be beneficial in preventing growth of pathogenic organisms, reducing inflammation and allergies, helping control over dysbiotic bacterial overgrowth and reduction of intestinal permeability.
Bifidobacterium and Lactobacillus may help to ward off pathogens like Salmonella and Clostridium botulinum [8]. There have been several reports in implicating the microbial flora in the pathogenesis of obesity $[9,10]$, diabetes $[10,11]$ and chronic kidney disease [12].

The present study attempted to evaluate the effect of fructose feed on protein glycation in the gut and other tissues and study of the use of protein glycation inhibitors can prevent such processes. It was also intended to study, if the use of probiotics can prevent the gut microbial changes and help to stop progression of diabetes.

\section{MATERIALS AND METHODS}

\section{Chemicals and materials}

Chemicals and reagents used were of analytical grade and purchased from local authorized distributors. Amino guanidine carbonate salt (AMG) was purchased from Sigma-Aldrich (St. Louis, MO, USA).

Blood glucose level was determined by using ACCU-CHEK kit (Roche Diagnostics, Manheim, Germany).

The Prebiotic and probiotic combination sachet (EUGITM) manufactured by WALLACE Pharmaceuticals Pvt. Ltd., Mumbai was obtained locally.

\section{Experimental animals}

Male Wistar rats weighing about 190-200 g were used in the experiment. All the animals were maintained under laboratory conditions and were allowed free access to food (Amruth, Pune) and water ad libitum. Animal experiments were carried out as per the guidelines of animal ethical committee of the Institute and CPCSEA (Registration no. 233/CPCSEA). 


\section{In vivo experimental design}

The animals $(n=4)$ were divided into five groups viz.

Group I: Control (without fructose feed)

Group II: Diabetic control: Diabetes was induced by giving a single dose of streptozotocin $[40 \mathrm{mg} / \mathrm{kg}$ of body weight (BW)] through intraperitoneal route, in $0.1 \mathrm{M}$ citrate buffer of $\mathrm{pH} 4.5$, prepared freshly and animals were monitored for a period of $14 \mathrm{~d}$ to confirm diabetes.

Group III: Non-diabetic rats with fructose feed $(10 \mathrm{~g} / \mathrm{d})$

Group IV: Non-diabetic rats with fructose feed $(10 \mathrm{~g} / \mathrm{d})+7 \mathrm{mg} / \mathrm{kg}$ BW AMG twice in a day.

Group V: Non-diabetic rats with fructose feed $(10 \mathrm{~g} / \mathrm{d})+50 \mathrm{mg}$ prebiotic and probiotic combination (EUGI) [Fructo oligo saccharides (300 mg), Lactobacillus acidophilus, Lactobacillus rhamnosus, Bifidobacterium longum, Bifidobacterium bifidum, Streptococcus thermophilus ( 0.24 billion of each) and Saccharomyces boulardii $(0.05$ billion $)=1 \mathrm{~g}]$ twice in a day.

The effect of doses was tested for $7 \mathrm{~d}$ of treatment. After the end of experiment, all the animals were fasted for $24 \mathrm{~h}$ and sacrificed to measure the biochemical parameters.

\section{Oral glucose tolerance test}

For performing OGTT, the rats were fasted overnight with free access to water ad libitum. Initial blood glucose level of each rat was checked. All the rats were fed orally with a glucose load of $3 \mathrm{mg} / \mathrm{g} \mathrm{BW}$. Blood samples were withdrawn from the tail vain at the time intervals of 0 min, $30 \mathrm{~min}, 60 \mathrm{~min}$ and $120 \mathrm{~min}$ after glucose administration and blood glucose was measured using ACCU-CHECK glucometer.

\section{Determination of serum parameters}

Blood glucose level was determined by using ACCU-CHECK glucometer. Total triglycerides and high-density lipoprotein (HDL) levels were measured by using commercially available kits (Span Diagnostics, Surat, Gujrat, India). Serum creatinine and total cholesterol were measured by diagnostic kit (Creast Biosynthesis, Goa, India; Biolab Diagnostics, Boisar, India). Very low-density lipoprotein (VLDL) levels were calculated from total cholesterol and HDL cholesterol values.

\section{Determination of antioxidant status of liver and kidney}

Kidney and liver were homogenized in $100 \mathrm{mmol}$ of Tris-HCl buffer pH 7.4 using Teflon homogenizer. The homogenate was centrifuged at $9000 \mathrm{rpm}$ for $20 \mathrm{~min}$ at $4{ }^{\circ} \mathrm{C}$ and supernatant was used for the estimation of superoxide dismutase (SOD) and catalase (CAT). Protein content was estimated by using Bradford method [13].

Superoxide dismutase was estimated using the method described by Mishra and Fridovich (1972) [14]. In brief, $0.1 \mathrm{ml}$ of supernatant was added to $3.5 \mathrm{ml}$ buffer (phosphate buffer $50 \mathrm{mmol}, \mathrm{pH} 7.4$ ), $0.3 \mathrm{ml}$ of $10 \mathrm{mmol}$ ethylene diamine tetra acetate (EDTA), $1.2 \mathrm{ml}$ of $130 \mathrm{mmol}$ methionine and $0.6 \mathrm{ml}$ of $150 \mu \mathrm{M}$ nitro blue tetrazolium (NBT) in 100 mmol sodium carbonate buffer, $\mathrm{pH}$ 10.35. Similarly prepared a reaction mixture in which supernatant was replaced by equal volume of distilled water which served as blank and was placed at dark. The reaction was started by addition of $0.4 \mathrm{ml}$ riboflavin $(60 \mu \mathrm{M})$. The tubes were radiated in front of $18 \mathrm{~W}$ fluorescent bulb for $30 \mathrm{~min}$ and the reaction was stopped by placing the tubes in dark. The absorbance was read at $560 \mathrm{~nm}$. Unit of SOD is described as the amount of enzyme required for inhibition of $50 \%$ oxidation riboflavin.

Catalase activity was determined from liver and kidney as per method described by Beers and Sizer (1952) [15]. The change in optical density at $240 \mathrm{~nm}$ per unit time was taken as a measure of catalase activity. Phosphate buffer $(100 \mathrm{mmol}, 7.4 \mathrm{pH}) 2.1 \mathrm{ml}$ was taken into a cuvette and $50 \mu \mathrm{l}$ of homogenate was added in the reaction mixture. Reaction was started by addition of $0.5 \mathrm{ml}$ freshly prepared $30 \mathrm{mmol} \mathrm{H}_{2} \mathrm{O}_{2}$ solution. The rate of decomposition of $\mathrm{H}_{2} \mathrm{O}_{2}$ was measured immediately by using UV-Visible spectrophotometer at $240 \mathrm{~nm}$. The activity of catalase was expressed in units per mg protein calculated by following formula,
Enzyme Activity (U/mg protein)

$$
=\frac{\Delta \mathrm{A} \times 1000 \times \text { Total reaction Vol. }}{\text { Extinction Coefficient } \times \text { Vol. of enzyme }}
$$

Where, Extinction coefficient $=43.6 / \mathrm{M} / \mathrm{cm}$

\section{Measurement of total reactive oxygen species (ROS) in liver}

The ROS were measured using a fluorescent 2', 7'-dichlorofluorescin diacetate (DCF-DA) dye [16]. The $100 \mathrm{mg}$ of liver tissue was chopped and incubated with $1 \mathrm{ml}$ of $10 \mathrm{mmol}$ DCF-DA for $30 \mathrm{~min}$ at $37^{\circ} \mathrm{C}$. After incubation the samples were sonicated for 15 seconds with 3 strokes and centrifuged for $4000 \mathrm{rpm}$ for $5 \mathrm{~min}$ at $4{ }^{\circ} \mathrm{C}$ and the fluorescence of supernatant was measured using spectrofluorimeter (Cary Eclipse Fluorescence Spectrophotometer, USA) at $488 \mathrm{~nm}$ excitation wavelength and $530 \mathrm{~nm}$ emission wavelength. DCF-DA is a non-polar compound that readily diffuses into cell, where it is hydrolyzed to nonfluorescent polar derivative DCFH and thereby trapped within the cells. In the presence of ROS, DCFH is oxidized to the highly fluorescent 2', 7'-dichlorofluorescein (DCF). The level of DCF fluorescence reflects the concentration of ROS.

\section{Measurement of tissue fluorescence-liver, kidney and intestine}

After sacrifice the rat's liver, kidney and intestine were washed with saline, minced and defatted with the mixture of chloroform and methanol $(2: 1 \mathrm{v} / \mathrm{v})$ overnight. The tissues were homogenized in $0.1 \mathrm{~N}$ $\mathrm{NaOH}$ and centrifuged at $10,000 \mathrm{rpm}$ for $30 \mathrm{~min}$ at $4{ }^{\circ} \mathrm{C}$ temperature. The amount of total $(370 / 440 \mathrm{~nm})$ and specific $(335 / 385 \mathrm{~nm})$ AGEs from the supernatant was measured using a spectrofluorimeter. The fluorescence intensities of the samples were measured and represented in terms of arbitrary units (AU) per mg of protein [17].

\section{Statistical analysis}

All the values were analysed by one-way analysis of variance (ANOVA). Obtained results were expressed as mean $\pm S D$ for four rats in each group $(n=4)$. $p$-value $<0.05$ were considered as significant.

\section{RESULTS}

\section{Effect of treatment on oral glucose tolerant test (OGTT)}

The effect of fructose feed was studied on the oral glucose tolerant test after $7 \mathrm{~d}$ of treatment. The rats fed with only fructose showed an increase in the blood glucose level. The OGTT pattern shows that, in fructose fed animals the blood glucose level significantly increased up to $154 \mathrm{mg} / \mathrm{dl}$ at $30 \mathrm{~min}$ while rats feed with fructose+AMG and fructose+EUGI shows the blood glucose level $137 \mathrm{mg} / \mathrm{dl}$ and 119 $\mathrm{mg} / \mathrm{dl}$ respectively (fig. 1 ).

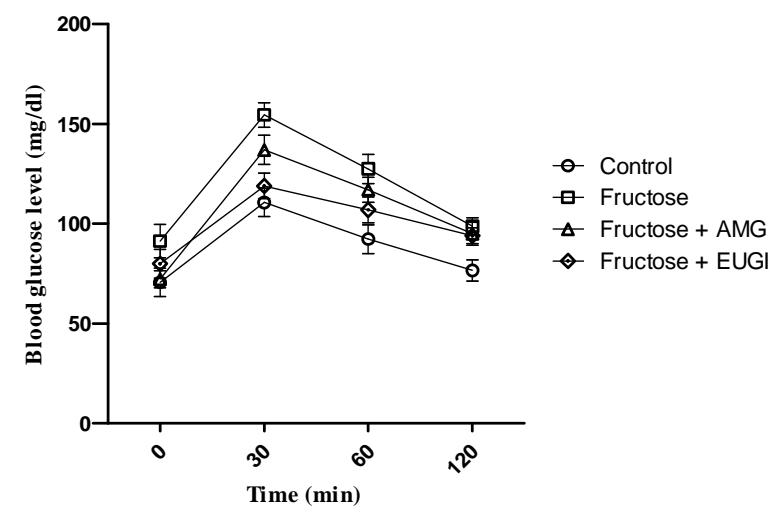

Fig. 1: Oral glucose tolerance test of experimental animals. Values were represented as mean $\pm \operatorname{SD}(n=4$.

\section{Body weight and serum parameter studies}

Animals fed with only fructose progressively gained more weight $(250 \mathrm{~g})$ than other animals and also demonstrated an increase in the fasting blood glucose level $(95 \mathrm{mg} / \mathrm{dl})$. While in fructose+AMG fed 
animals the blood glucose level was $71 \mathrm{mg} / \mathrm{dl}$ as similar that of control $(67.2 \mathrm{mg} / \mathrm{dl})$. The AMG and EUGI treated animal shows significant reduction in serum lipid profile as compared to the fructose fed group (table 1).

Serum creatinine has been found to be a reliable indicator of kidney function. In fructose feed animals the serum creatinine level found slightly increased $(0.725 \mathrm{mg} / \mathrm{dl})$ than that of control $(0.575 \mathrm{mg} / \mathrm{dl})$, fructose + AMG $(0.575 \mathrm{mg} / \mathrm{dl})$ and EUGI treated animals $(0.550$ $\mathrm{mg} / \mathrm{dl}$ ) (table 1).

\section{Urine volume}

Urine volume and rate of excretion was significantly increased in fructose feed animal group as compared to other treatment groups (table 1).

Table 1: Effect of in vivo treatment on body weight, blood and urine parameters in experimental animals

\begin{tabular}{|c|c|c|c|c|c|c|c|}
\hline \multirow[t]{2}{*}{$\begin{array}{l}\text { S. } \\
\text { No. }\end{array}$} & \multirow[t]{2}{*}{ Tissue/Sample } & \multirow{2}{*}{$\begin{array}{l}\text { Parameter } \\
\text { Fructose dose }\end{array}$} & \multirow{2}{*}{$\begin{array}{l}\text { Control } \\
\text { No fructose } \\
\end{array}$} & \multirow{2}{*}{$\begin{array}{l}\begin{array}{l}\text { Diabetic } \\
\text { control }\end{array} \\
\text { No fructose } \\
\end{array}$} & \multicolumn{3}{|c|}{ Non-Diabetic Groups } \\
\hline & & & & & Fructose & Fructose+AMG & Fructose+EUGI \\
\hline 1 & & Weight (g) & $230.3 \pm 7.789$ & $228.2 \pm 6.321$ & $250.5 \pm 4.893$ & $245.6 \pm 6.498$ & $249.3 \pm 3.951$ \\
\hline \multirow[t]{8}{*}{2} & Blood/Serum & $\begin{array}{l}\text { A) Initial Blood glucose } \\
\text { (mg/dl) }\end{array}$ & $66.0 \pm 3.91$ & $202.0 \pm 14.31$ & $66.5 \pm 4.43$ & $65.25 \pm 4.42$ & $64.75 \pm 2.50$ \\
\hline & & $\begin{array}{l}\text { B). Blood glucose }(\mathrm{mg} / \mathrm{dl}) \\
\text { C) Lipid profile test (mg \%) }\end{array}$ & $67.25 \pm 4.92$ & $203.3 \pm 17.15$ & $95.00 \pm 4.16$ & $71.00 \pm 8.83^{*}$ & $79.00 \pm 4.69 *$ \\
\hline & & i] Total Cholesterol & $58.0 \pm 4.32$ & $130.5 \pm 9.67$ & $83.00 \pm 2.58$ & $68.00 \pm 4.32 *$ & $72.75 \pm 5.70$ \\
\hline & & ii] S. Triglycerides & $59.0 \pm 6.83$ & $147.0 \pm 14.65$ & $167.0 \pm 10.13$ & $85.0 \pm 12.91^{*}$ & $75.50 \pm 5.00 *$ \\
\hline & & iii] S. HDL Cholesterol & $41.50 \pm 2.64$ & $39.00 \pm 2.58$ & $37.00 \pm 2.58$ & $30.75 \pm 2.21^{*}$ & $27.25 \pm 2.21^{*}$ \\
\hline & & iv] VLDL Cholesterol & $11.00 \pm 2.58$ & $29.50 \pm 3.41$ & $32.50 \pm 3.41$ & $18.00 \pm 1.63^{*}$ & $13.25 \pm 2.21^{*}$ \\
\hline & & D) Urea $(\mathrm{mg} / \mathrm{dl})$ & $23.25 \pm 3.59$ & $64.0 \pm 9.76$ & $30.25 \pm 1.70$ & $23.5 \pm 3.10^{*}$ & $24.0 \pm 1.82^{*}$ \\
\hline & & E) Creatinine $(\mathrm{mg} / \mathrm{dl})$ & $0.575 \pm 0.05$ & $2.60 \pm 0.216$ & $0.725 \pm 0.05$ & $0.575 \pm 0.05^{*}$ & $0.550 \pm 0.05^{*}$ \\
\hline 3 & Urine & Volume (ml/day) & $14.50 \pm 2.08$ & $32.75 \pm 5.25$ & $20.25 \pm 2.38$ & $15.75 \pm 1.70 *$ & $16.00 \pm 1.63^{*}$ \\
\hline
\end{tabular}

Each value expressed as means $\pm S D,(n=4)$. ${ }^{*}$ values significant at $\mathrm{P}<0.05$ as against fructose fed.

\section{Effect on antioxidant status and tissue fluorescence}

The in vivo antioxidant status was evaluated in terms of liver and kidney SOD and catalase enzyme activity. In fructose fed animals liver and kidney SOD activities were reduced significantly ( 6.37 and $11.25 \mathrm{U} / \mathrm{mg}$ of protein respectively) as compared to control group. While in fructose+AMG treated group the values are nearly equal to that of control group. Similarly, the liver and kidney catalase activities in fructose fed group are significantly decreased (186 and $65.5 \mathrm{U} / \mathrm{mg}$ of protein) as that of control group. In fructose+AMG treated animals the liver and kidney catalase values are 204 and $95.75 \mathrm{U} / \mathrm{mg}$ of protein respectively. While EUGI treated animals the liver and kidney SOD values are 7.2 and $14.53 \mathrm{U} / \mathrm{mg}$ and catalase values are 200 and $83.75 \mathrm{U} / \mathrm{mg}$ of protein respectively (table 2).

There is 5-6 fold increase in general and specific fluorescence of fructose fed animals as compared to control animals. In control and fructose+AMG fed animals it was 2.86 and $4.42 \mathrm{AU} / \mathrm{mg}$ respectively.
The tissue fluorescence of all the tissues increased significantly in fructose feed animals than of the control, fructose+AMG and EUGI treated animals (table 2).

\section{Fluorescence of intestine}

There is 5 and 4 fold increase in general and specific fluorescence of intestine (duodenum) in fructose feed animals than that of control group ( 0.426 and $0.807 \mathrm{AU} / \mathrm{mg}$ resp.). In AMG treated animals these values are 0.511 and $0.924 \mathrm{AU} / \mathrm{mg}$ as similar with control group. EUGI treatment found efficiently reducing the rate of protein glycation (0.902 and $2.147 \mathrm{AU} / \mathrm{mg}$ resp.) (table 2).

\section{Liver reactive oxygen species (ROS)}

Fructose feed animals showed a 2.2 fold increase in generation of ROS in liver as compared to that of control ( $1.47 \mathrm{AU} / \mathrm{mg}$ of tissue). While in AMG and EUGI treated animals it is 2.8 and $2.96 \mathrm{AU} / \mathrm{mg}$ of tissue respectively (table 2).

Table 2: Status of antioxidant parameters and tissue fluorescence in experimental animals

\begin{tabular}{|c|c|c|c|c|c|c|c|}
\hline \multirow[t]{2}{*}{ S. No. } & \multirow[t]{2}{*}{ Tissue/Sample } & \multirow[t]{2}{*}{ Parameter } & \multirow[t]{2}{*}{ Control } & \multirow{2}{*}{$\begin{array}{l}\text { Diabetic } \\
\text { control }\end{array}$} & \multicolumn{3}{|c|}{ Non-Diabetic Groups } \\
\hline & & & & & Fructose & Fructose+AMG & Fructose+EUGI \\
\hline \multirow[t]{5}{*}{1} & Liver & a) SOD (U/mg of protein) & $9.000 \pm 0.432$ & $4.000 \pm 0.816$ & $6.375 \pm 0.464$ & $8.275 \pm 0.377^{*}$ & $7.225 \pm 0.434$ \\
\hline & & b) CAT (U/mg of protein) & $223.8 \pm 8.098$ & $123.3 \pm 9.069$ & $186.3 \pm 4.787$ & $204.0 \pm 6.325^{*}$ & $200.8 \pm 6.500^{*}$ \\
\hline & & Fluorescence & $0.235 \pm 0.026$ & $8.240 \pm 0.796$ & $4.463 \pm 0.613$ & $1.009 \pm 0.154^{*}$ & $1.611 \pm 0.282^{*}$ \\
\hline & & $\begin{array}{l}\text { i] General }(\mathrm{AU} / \mathrm{mg}) \\
\text { ii] Specific }(\mathrm{AU} / \mathrm{mg})\end{array}$ & $0.842 \pm 0.065$ & $13.69 \pm 0.871$ & $4.319 \pm 0.272$ & $1.872 \pm 0.119 *$ & $3.018 \pm 0.095^{*}$ \\
\hline & & $\mathrm{ROS}(488 / 520) \mathrm{AU} / \mathrm{mg}$ of Tissue & $1.477 \pm 0.193$ & $4.017 \pm 0.189$ & $3.207 \pm 0.098$ & $2.805 \pm 0.103$ & $2.965 \pm 0.034$ \\
\hline \multirow[t]{4}{*}{2} & Kidney & c) SOD (U/mg of protein) & $19.00 \pm 2.94$ & $7.425 \pm 0.512$ & $11.25 \pm 1.708$ & $15.55 \pm 1.215^{*}$ & $14.53 \pm 1.176^{*}$ \\
\hline & & d) CAT (U/mg of protein) & $112.2 \pm 5.901$ & $44.75 \pm 4.787$ & $65.5 \pm 4.435$ & $95.75 \pm 3.775^{*}$ & $83.75 \pm 6.449^{*}$ \\
\hline & & $\begin{array}{l}\text { Fluorescence } \\
\text { i] General }(\mathrm{AU} / \mathrm{mg})\end{array}$ & $1.20 \pm 0.184$ & $6.651 \pm 0.429$ & $4.663 \pm 0.423$ & $1.50 \pm 0.225^{*}$ & $2.73 \pm 0.354^{*}$ \\
\hline & & ii] Specific (AU/mg) & $2.86 \pm 0.393$ & $15.66 \pm 2.336$ & $17.57 \pm 1.284$ & $4.429 \pm 1.028^{*}$ & $12.66 \pm 1.732 *$ \\
\hline \multirow[t]{2}{*}{3} & Intestine & Fluorescence & $0.426 \pm 0.033$ & $0.938 \pm 0.100$ & $2.180 \pm 0.330$ & $0.511 \pm 0.070^{*}$ & $0.902 \pm 0.058^{*}$ \\
\hline & & $\begin{array}{l}\text { i] General }(\mathrm{AU} / \mathrm{mg}) \\
\text { ii] Specific }(\mathrm{AU} / \mathrm{mg})\end{array}$ & $0.807 \pm 0.102$ & $1.640 \pm 0.235$ & $3.100 \pm 0.331$ & $0.924 \pm 0.110^{*}$ & $2.147 \pm 0.116^{*}$ \\
\hline
\end{tabular}

Each value expressed as means $\pm S D,(n=4)$. *values significant at $\mathrm{P}<0.05$ as against fructose fed.

\section{DISCUSSION}

Earlier attempts in our lab have demonstrated that fructose is more efficient in glycation of protein than glucose hence it has chosen for the experiments. Further whether these changes can be prohibited leading to positive outcomes is evaluated. High fructose feed have influenced drastic changes in the whole body within a span of $7 \mathrm{~d}$. It was observed that there is extensive glycation of various tissues and a strong 
oxidative stress is initiated. These changes can snowball into various metabolic disorders. In a study conducted by Prakash et al. in 2011 [18] demonstrated that high fructose feeding in rat leads to impaired glucose tolerance and insulin resistance. It has been reported that, modulating composition of gut flora with prebiotics improved gut permeability, reduced metabolic endotoxemia, lowered inflammation, and alleviated glucose intolerance $[19,20]$. Recent clinical study suggesting that gut microbiota modulation with novel probiotics prevents and efficiently controls type II diabetes along with its complications [21]. In support to these work we have found that, an oral glucose tolerance test in the various treated groups also demonstrates prevention in a shift towards a diabetic curve as seen in fructose fed rats and reduction in postprandial spikes is one of the major strategies to prevent establishment of diabetes through the use of probiotics and protein glycation inhibitors.

It is surprising to note that fructose feed for seven days led to an increase in fasting blood glucose level and influences the lipid profile of the animals (table 1). Use of aminoguanidine, a protein glycation inhibitor prevents such changes to a greater extent. Likewise the probiotics also seem to have a beneficial effect. It is significant that a fructose feed of 10 $\mathrm{g} / \mathrm{d}$ influenced such chronic changes in serum creatinine and increased urine excretion. Oxidative stress helps to accelerate pathological conditions in diabetes [22-24] and promotes the rate of protein glycation $[25,26]$. So, we attempted to study the effect of probiotics and glycation inhibitor AMG on ROS formation, antioxidant status and tissue fluorescence. The oxidative stress is also found to increase in the tissues such as the liver and kidney and is found to be reduced on treatment. The extent of protein glycation has been evaluated through study of general and specific fluorescence. The increase in tissue fluorescence indicates the extent of glycation. The general and specific fluorescence of liver and kidney increased significantly in fructose fed animals. Hyperglycemia causes glucose auto-oxidation, protein glycation, protein kinase $\mathrm{C}$ activation and lipid peroxidation which further results in generation of reactive oxygen species [27, 28]. Fructose feeding significantly increased rate of ROS generation in liver as compared to that of control animals. The glycated intestinal proteins presented an evidence for adverse effect of excess fructose feeding on healthy gut, promoting the prediabetic state.

\section{CONCLUSION}

In conclusion, this preliminary study throws light on the impact of high fructose feed on glycation of proteins and probable changes on such glycation. Fructose feed can greatly influence changes in the whole body in just $7 \mathrm{~d}$ implying that such repeated insults can eventually lead to establishment of diabetes. It is interesting to note that while aminoguanidine can inhibit protein glycation significantly, use of probiotics also demonstrate a similar effect points to the importance of gut microbiota in promoting positive changes. Thus the present study raises the possibility of prevention of establishment of diabetes and its progression through use of protein glycation inhibitors and prebiotics and probiotics.

\section{ABBREVIATIONS}

Oral glucose tolerance test-OGTT, aminoguanidine-AMG, superoxide dismutase-SOD, catalase-CAT, cardio vascular diseases-CVD, advanced Glycation Products-AGEs, body weight-BW, prebiotic and probiotic combination-EUGI, high-density lipoprotein-HDL, very low-density lipoprotein-VLDL, ethylene diamine tetra acetate-EDTA, nitro blue tetrazolium-NBT, reactive oxygen species-ROS, 2', 7'dichlorofluorescin diacetate-DCF-DA, 2', 7'-dichlorofluorescein-DCF, arbitrary units-AU, standard deviation-SD.

\section{AUTHORS CONTRIBUTIONS}

RSP and AUA have designed the research work, RSP, ADJ, MLN and LNB have performed the experiments. All authors equally contributed to drafting the paper. All authors have read and approved the final manuscript.

\section{ACKNOWLEDGEMENT}

The present investigation received financial support from Department of Science and Technology (DST), New Delhi, India in the form of DST-INSPIRE (JRF) fellowship to Rahul Shivaji Patil.

\section{CONFLICT OF INTERESTS}

All authors have none to declare

\section{REFERENCES}

1. Joglekar MM, Panaskar SN, Chougale AD, Kulkarni MJ, Arvindekar AU. A novel mechanism for antiglycative action of limonene through stabilization of protein conformation. Mol BioSyst 2013;9:2463-72.

2. Dethlefsen L, Eckburg PB, Bik EM, Relman DA. Assembly of the human intestinal microbiota. Trends Ecol Evol 2006;21:517-23.

3. Dethlefsen L, McFall-Ngai M, Relman DA. An ecological and evolutionary perspective on human-microbe mutualism and disease. Nature 2007;449:811-8.

4. Ley RE, Peterson DA, Gordon JI. Ecological and evolutionary forces shaping microbial diversity in the human intestine. Cell 2006;124:837-48.

5. Aw W, Fukuda S. Understanding the role of the gut ecosystem in diabetes mellitus. J Diabetes Investig 2018;9:5-12.

6. Bibbo S, Dore MP, Pes GM, Delitala G, Delitala AP. Is there a role for gut microbiota in type 1 diabetes pathogenesis? Ann Med 2017;49:11-22.

7. Knip M, Siljander H. The role of the intestinal microbiota in type 1 diabetes mellitus. Nat Rev Endocrinol 2016;12:154-67.

8. Alison Abbott. Gut reaction: consumers are stocking up on live yoghurts and fermented drinks that claim to improve health. But is there any science behind the marketing of these 'probiotic' products? Nature 2004;427:284-6.

9. Turnbaugh PJ, Ley RE, Mahowald MA. An obesity associated gut microbiome with increased capacity for energy harvest. Nature 2006;444:1027-31.

10. Turnbaugh PJ, Hamady M, Yatsunenko T. A core gut microbiome in obese and lean twins. Nature 2009;457:480-4.

11. Qin J, Li Y, Cai Z. A metagenome-wide association study of gut microbiota in type 2 diabetes. Nature 2012;490:55-60.

12. Mishima E, Fukuda S, Shima H. Alteration of the intestinal environment by lubiprostone is associated with amelioration of adenine-induced CKD. J Am Soc Nephrol JASN 2015;26:1787-94.

13. Bradford MM. A rapid and sensitive method for the quantitation of microgram quantities of protein utilizing the principle of protein-dye binding. Anal Biochem 1976;72:248-54.

14. Misra HP, Fridovich I. The role of superoxide anion in the autoxidation of epinephrine and a simple assay for superoxide dismutase. J Biol Chem 1972;247:3170-5.

15. Beers RF, Sizer IW. A Spectrophotometric method for measuring the breakdown of hydrogen peroxide by catalase. J Biol Chem 1952;195:133-40.

16. Yeligar SM, Harris FL, Hart CM, Brown LAS. Ethanol induces oxidative stress in alveolar macrophages via upregulation of NADPH oxidases. J Immunol 2012;188:3648-57.

17. Panaskar SN, Joglekar MM, Taklikar SS, Haldavnekar VS, Arvindekar AU. Aegle marmelos Correa leaf extract prevents secondary complications in streptozotocin-induced diabetic rats and demonstration of limonene as a potent antiglycating agent. J Pharm Pharmacol 2013;65:884-94.

18. Prakash P, Khanna V, Singh V, Jyoti A, Jain M, Keshari RS, et al. Atorvastatin protects against ischemia-reperfusion injury in fructose-induced insulin resistant rats. Cardiovasc Drugs Ther 2011;25:285-97.

19. Cani PD, Possemiers S, Van de Wiele T, Guiot Y, Everard A, Rottier $\mathrm{O}$, et al. Changes in gut microbiota control inflammation in obese mice through a mechanism involving GLP-2-driven improvement of gut permeability. Gut 2009;58:1091-103.

20. Everard A, Lazarevic V, Derrien M, Girard M, Muccioli GG. Responses of gut microbiota and glucose and lipid metabolism to prebiotics in genetic obese and diet-induced leptin-resistant mice. Diabetes 2011;60:2775-86.

21. Palacios T, Vitetta L, Coulson S, Madigan CD, Denyer GS, Caterson ID. The effect of a novel probiotic on metabolic biomarkers in adults with prediabetes and recently diagnosed type 2 diabetes mellitus: study protocol for a randomized controlled trial. Trials 2017;18:7.

22. Abdul-Ghani MA, DeFronzo RA. Oxidative stress in type 2 diabetes mellitus. In: Miwa S, Beckman K, Muller F. editors. 
Oxidative stress in aging. Humana Press; Totowa NJ, USA; 2008. p. 191-211.

23. Giacco F, Brownlee M. Oxidative stress and diabetic complications. Circ Res 2010;107:1058-70.

24. Henriksen EJ, Diamond Stanic MK, Marchionne EM. Oxidative stress and the etiology of insulin resistance and type 2 diabetes. Free Radical Biol Med 2011;51:993-9.

25. Wolff SP, Jiang, ZY, Hunt JV. Protein glycation and oxidative stress in diabetes mellitus and ageing. Free Radical Biol Med 1991;10:339-52.
26. El-Baz FK, Aly HF, Khalil WK, Ali GH, Hafiz NA, Saad SA. Potential role of Haematococcus pluvialis against diabetes induced oxidative stress and inflammation in rats. Asian J Pharm Clin Res 2017; 10:245-51.

27. Niedowicz DM, Daleke DL. The role of oxidative stress in diabetic complications. Cell Biochem Biophys 2005;43:289330.

28. Sarhan KK, Mohammed, Alias, Mebin, Kumar R, Sambath. A review on novel uses of Vitamin E. J Crit Rev 2018;5:10-4. 